\title{
THE ORIGIN OF MODERN CHIAPANECAN VOLCANIC ARC IN SOUTHERN MEXICO INFERRED FROM THERMAL MODELS
}

\author{
by \\ Vlad C. Manea ${ }^{1}$ and Marina Manea ${ }^{2}$
}

1,2 Seismological Laboratory 252-21, CalTech, Pasadena, CA 91125, USA

${ }^{1}$ e-mail: vlad@gps.caltech.edu

2 e-mail: marina@gps.caltech.edu

Manuscript to be submitted to a GSA Special Paper "Natural Hazards in Central America"

March, 2005 


\section{ABSTRACT}

Southern Mexico is a very interesting area where the subducting Cocos slab drastically changes its geometry: from a flat slab in Central Mexico to a $\sim 45^{\circ}$ dip angle beneath Chiapas. Also, the currently active volcanic arc, the modern Chiapanecan volcanic arc, is oblique and situated far inland from the Middle America trench, where the slab depth is $200 \mathrm{~km}$. In contrast, the Central America volcanic arc is parallel to the Middle America trench and the slab depth is $\sim 100 \mathrm{~km}$. A 2D steady state thermo-mechanical model explains the calc-alkaline volcanism by high temperature ( $1300^{\circ} \mathrm{C}$ ) in the mantle wedge just beneath the Central America volcanic arc and strong dehydration ( 5 wt.\%) of the Cocos slab. In contrast, the thermal model for the modern Chiapanecan volcanic arc shows high P-T conditions beneath the coast where the Miocene Chiapanecan extinct arc is present, and is therefore unable to offer a reasonable explanation for the origin of the modern Chiapanecan volcanic arc. We propose a model in which the origin of the modern Chiapanecan volcanic arc is related to the space-time evolution of the Cocos slab in Central Mexico. The initiation of flat subduction in Central Mexico in the middle Miocene would have generated a hot mantle wedge inflow from NW to SE, generating the new modern Chiapanecan volcanic arc. Because of the contact between the hot mantle wedge beneath Chiapas and the proximity of a newly formed cold flat slab, the previous hot mantle wedge in Chiapas became colder in time, finally leading to the extinction of the Miocene Chiapanecan volcanic arc. The position and the distinct Kalkaline volcanism at El Chichón volcano are proposed to be related to the arrival of the highly serpentinized Tehuantepec Ridge beneath modern Chiapanecan volcanic arc. The deserpentinization

of Tehuantepec Ridge would have released significant amounts of water into the overlying mantle, therefore favoring vigorous melting of the mantle wedge and probably of the slab.

Keywords: Chiapanecan volcanic arc, thermal models, alkaline volcanism, flat subduction. 


\section{INTRODUCTION}

One of the most interesting volcanic areas in Mexico is located in the southern part, in Chiapas. Here, the volcanism is characterized by two Neogene volcanic arcs: the ancestral Miocene Sierra Madre arc and the modern Chiapanecan volcanic arc (MCVA) (Figure 1). The Miocene Sierra Madre arc was abandoned between 9 and $3 \mathrm{Ma}$, when the MCVA was formed (Damon and Montesinos, 1978). There are a series of characteristics that make this new MCVA special. First, the position of the arc is well inside the continent, at distances of 300 - $350 \mathrm{~km}$ from the Middle America trench (MAT). The subducting Cocos slab lies $200 \mathrm{~km}$ below the MCVA, whereas the majority of subduction related volcanic arcs are located where the slab is at $\sim 100 \mathrm{~km}$ depth. Second, although there is a little variation of the slab dip beneath Chiapas (40 - 45) (Rebollar et al., 1999), the MCVA shows an oblique trending with the MAT of $\sim 30^{\circ}$. The MCVA holds typical continental arc calc-alkaline magmas (Damon and Montesinos, 1978), but with one exception: El Chichón volcano. This volcano presents a transitional magma signature from calc-alkaline to adakitic-like type (Macias et al., 2003; De Ignacio et al., 2003). This character was associated with melting of the Cocos slab just beneath at $~ 200 \mathrm{~km}$ by De Ignacio et al. (2003). The triple junction proximity between the North America, Cocos and Caribbean plates was proposed by Nixon (1982) as a cause for the alkaline volcanism of El Chichón. Other authors suggest that this volcano is associated with the subduction of the Cocos plate (Luhr et al., 1984; Bevis and Isacks, 1984). The northwesternmost closest neighbor of the MCVA is the isolated Tuxtla Volcanic Front (TVF). On the basis of trace element studies, the Na-alkaline products of TVF are explained by Nelson et al. (1995) to be generated from mantle and continental crust melts contaminated by fluids or melts expelled from the subducted lithosphere. To the south, after a gap of $\sim 100 \mathrm{~km}$, the closest neighbor of the MCVA is the calc-alkaline volcano Tacana, which belongs to the Central American volcanic arc (CAVA) (Garcia-Palomo et al., 2004). Although, the slab dip, age and convergence rate of the Cocos slab beneath the CAVA in Guatemala are very similar to those beneath Chiapas, the two active volcanic arcs are in completely different locations. Therefore, it is likely that an external perturbation source of the mantle wedge flow is responsible for this anomalous MCVA. Anisotropy in the form of share wave splitting has been observed in many subduction zones (Kuril, Japan, Tonga, Izu-Bonin), and appear to be related with the asthenospheric flows produced by present-day plate motion (Fischer et al., 2000). Since, thermal and flow models in the mantle wedge can give us advance insights on the geodynamic processes beneath the volcanic arcs, we compute four 2D thermal models normal to MAT, three in southern Mexico and one in Guatemala, using the 
numerical approach proposed by Manea et al. (2005-C).

The relationship between the long-term evolution of the subducting Cocos slab and the

origin of MCVA has never been addressed so far. In order to explain the unusual MCVA, we propose a geodynamic model mainly related with the initiation of flat subduction in early-middle Miocene (Ferrari et al., 1999) beneath Central Mexico. 


\section{TECTONIC SETTINGS}

The geometry of Wadati-Benioff zone shows that the Cocos slab increases its dip from $25^{\circ}$ just NW of TR in Oaxaca, to $\sim 40^{\circ}$ southeast of TR in Chiapas (Rebollar et al., 1999, Bravo et al., 2004). Then the slab slightly increases its dip to $\sim 45^{\circ}$ beneath the northern edge of the CAVA. Also the maximum depth extent of the intraslab earthquakes increases from $120 \mathrm{~km}$ in southern Oaxaca (Bravo et al., 2004) to $240 \mathrm{~km}$ in southern Chiapas (Rebollar et al., 1999).

Offshore, a very large linear feature, the Tehuantepec ridge (TR), represents a tectonic border between two different regions on the Cocos plate (Manea et al., 2004-A). Across TR, there is an age jump of the Cocos slab at the MAT of $~ 10 \mathrm{Ma}$, defining two different thermal gradients across the oceanic lithosphere (Figure 2). The seafloor age just northwest of TR is $\sim 16$ Ma (Kanjorsky, 2003; Klitgord and Mammerickx, 1982), then 26 Ma (Manea et al., 2004-B) in front of the Chiapas state, and then $\sim 23$ Ma in Guatemala (Manea et al, 2004-B). The rate of convergence between the Cocos plate and the North America and Caribbean plates varies from 6.5 cm/yr in Oaxaca to 7 cm/yr in Chiapas from NUVEL 1A model (DeMets et al., 1994).

Onshore, a very important tectonic feature is represented by the triple junction between three plates: North America, Cocos and Caribbean plates. The contact between NA and Caribbean plates is not very clear. Guzman and Meneses (2000) proposed that this contact is actually a diffuse boundary represented by a fault jog system.

There are two volcanic arcs in Chiapas: the ancient extinct Sierra Madre Miocene arc which runs parallel to the coast, and the MCVA further inland. The active volcanic arc is tilted by $\sim 30^{\circ}$ in respect with MAT. Damon and Montesinos (1978) show that the Miocene Sierra Madre arc was abandoned between 9 and $3 \mathrm{Ma}$, then the MCVA was born as a consequence of a reorganization of the Cocos plate. Using isotopic ages (Ar-Ar method) for Central Mexico, Ferrari et al. (1999) show that the position of volcanism in Central Mexico changed during the last $25 \mathrm{Ma}$, revealing that the Cocos slab became subhorizontal 20 Ma ago. 


\section{THERMAL MODELS AND MAGMATIC PRODUCTS}

In this study we developed four thermal models constrained by seismic data (Rebollar et al., 1999; Engdahl and Villaseñor, 2002), convergence rate (DeMets et al., 1994) and oceanic plate age at the MAT (Manea et al., 2004-B; Kanjorsky, 2003; Klitgord and Mammerickx, 1982) (Figure 3). The first profile was chosen just above TR because of the subhorizontal shape of the subducting Cocos slab. Because of the temperature-dependent viscosity, this model shows high temperature ( $1300^{\circ} \mathrm{C}$ ) beneath the volcanic arc. Using the phase diagram for basalt and harzburgite (Hacker et al., 2003), we can see that the slab geotherm intersects the dehydration melting solidus at $\sim 70 \mathrm{~km}$, implying that melting of the basaltic crust might take place at this depth (Figure 4). This is in good agreement with the conclusion of Nelson et al. (1995), who show that a constant ratio of $\mathrm{Ba} / \mathrm{Nb}$ is an indicator of magma contaminated by fluids or melts derived from the subducted slab. Also, a vertical P-T profile beneath TVF intersects the wet solidus for peridotite (Wyllie, 1979), this explaining the calc-alkaline signature of the volcanic material (Figure 4B). The second profile is situated just below TR and intersects the MCVA in the proximity of the El Chichón volcano. The modeling results show high temperatures beneath the ancient Miocene volcanic arc rather than beneath the MCVA (Figure 3B). The distant MCVA lies $200 \mathrm{~km}$ above the slab, where the entire oceanic slab is completely dehydrated. Also, the slab geotherm does not intersect the melting solidus for basalt (Figure 4A), therefore with this model we cannot explain the K-alkaline products of the El Chichón volcano. At this stage a 2D steady-state thermal model is inconsistent with the observations, but in the following chapters we will address these issues. The last two models are located at the northern edge of the CAVA (Figure 3C,D). The results show a region with high temperature $\left(\sim 1300^{\circ} \mathrm{C}\right)$ just beneath the active arc, well beyond the wet peridotite (Figure $4 B$ ). Also strong slab dehydration ( 5 wt.\%) lowers the melting point of mantle peridotite, and favors calc-alkaline volcanism. The slab geotherm does not intersect the basalt solidus, this being consistent with the pure calc-alkaline character of the CAVA (no Na-alkaline or K-alkaline products). 


\section{SPACE-TIME EVOLUTION OF THE COCOS SLAB AND CHIAPANECAN VOLCANISM}

One of the key issues in understanding the position through time of a subducting slab is the variation in time of volcanic arcs. Using the distribution of dated rocks of Ferrari et al. (1999) for Central Mexico, and of Damon and Montesinos (1978) for Chiapas, we propose the evolution of the subducting slab presented in Figure 5. Between 25 and 17 Ma ago, the volcanic arc formed an approximatively continuous belt in Central Mexico, Chiapas and Guatemala (Figure 5A). Then, between 17 and 12 Ma ago, the CMVB moved inland, suggesting that the subducting slab become subhorizontal (Figure 5B). To the south, the rest of the volcanic arc remained parallel with MAT, therefore suggesting that the slab approximately preserved its previous dip. Later, between 12 and 7 $\mathrm{Ma}$, the flattening process of the Cocos slab continued further SE, while the CAVA retreated SE (Figure 5C). Between 7 and $3 \mathrm{Ma}$ ago, the CAVA continued to retreat SE and the volcanic activity close to the Chiapas coast ceased completely (Figure 5D). The TVF was born during this time period. The last episode of this scenario took place between 3 and $0 \mathrm{Ma}$, and is represented by the onset of the MCVA (Figure 5E).

Since the slab dip, age and convergence rate of the Cocos slab beneath the Central American volcanic front in Guatemala are very similar to those beneath Chiapas, why are the two active volcanic arcs so different, and why are both not active? Therefore, to answer this question we looked for an external perturbation source responsible for the anomalous Chiapanecan volcanism. We propose that an external perturbation came from the time evolution of the subducting slab beneath Central Mexico. The onset of the flat slab just above TR, in Central Mexico, would have produced a strong mantle wedge inflow in the neighboring region to the SE (Figure 5B-E). This intake would have migrated over time, creating the tilted MCVA. The isotopic ages of the MCVA decrease from NW to SE (Figure 6), suggesting that the arc was propagating through time from NW to SE. If such a model can explain the position of the distant tilted MCVA, there is still one question that has to be addressed: why has the Sierra Madre volcanic arc ceased? To answer this question we look to the implication of the 3D temperature distribution of this region. The flat cold incoming oceanic lithosphere (profile A-A' in Figure 1) is in contact with the hot mantle wedge just $120 \mathrm{~km}$ $\mathrm{SE}$. The flat slab temperature is $\sim 600^{\circ} \mathrm{C}$, while the mantle wedge temperature is $\sim 1300^{\circ} \mathrm{C}$ (Figure $4 A, B)$. Therefore there is a continuous cooling of the mantle wedge beneath the ancient Chiapanecan volcanic arc. If a mantle wedge tip is cooled down, then a very interesting phenomena might appear. From the phase diagram for harzburgite (Figure $4 B$ ) we can see that during the 
cooling, the mantle wedge enters into the serpentine stability field $\left(\sim<600^{\circ} \mathrm{C}\right)$. The location of serpentinized mantle wedge tip is critical because it may control the down-dip coupling between the slab and the overlying material (Manea et al., 2004). Very low shear-wave velocities in the cold forearc mantle have been discovered in the southern Cascadia subduction zone (Bostock et al., 2002). This is evidence of a highly hydrated and serpentinized material in the forearc region. The same conditions should also be expected in the Chiapas subduction zone. 


\section{MODEL CONSTRAINTS}

To gather all these assumptions together, we developed a thermal model with a fixed mantle wedge tip which simulates the decoupling of the subducting slab due to mantle serpentinization, and a hot source $\left(1200^{\circ} \mathrm{C}\right)$ beneath the MCVA which represents the NW-SW asthenospheric intake. The results show a well developed serpentinized mantle wedge tip (Figure 7B). From Figure 8 it can be seen that the mantle wedge beneath Chiapas lies just in front of a cold area which corresponds to the flat slab. In order to investigate the existence of a cold and serpentinized mantle wedge beneath Chiapas, we need to look for some external constraints for our model. The serpentinization process has two major effects on the physical properties of peridotite: the density decreases from $\sim 3000 \mathrm{~kg} / \mathrm{m}^{3}$ to $2500 \mathrm{~kg} / \mathrm{m}^{3}$ (Christensen, 1966; Saad, 1969), and the remnant magnetization increases by at least an order of magnitude (Saad, 1969). A recent study of Blakely et al. (2004) demonstrates that magnetic mantle is a common feature in subduction zones like Cascadia, Japan and southern Alaska. The serpentinized mantle can be enlightened by the presence of a long-wavelength magnetic anomaly above subduction zones. The availability of a new magnetic map for North America (NAMAG, 2002) allows us to prove the existence of a large amount of serpentine in Chiapas. In Figure 9, aeromagnetic data display a distinctive long wavelength positive anomaly ( $500 \mathrm{nT}$ ) offshore Chiapas. Unfortunately, the maximum extent inland of the serpentinized wedge is not possible to be inferred because the magnetic data lack onshore Chiapas. Instead, the contact between Moho and the subducting Cocos slab is obtained using the onset of the strong positive magnetic anomaly. Since the magnetic anomaly has not been migrated to the pole, the source is not located just beneath. Figure 7A shows a 2D magnetic profile migrated to pole anomaly. The onset of the serpentinized mantle wedge is located at $\sim 125 \mathrm{~km}$ from the trench, and runs parallel to the MAT. This provides a Moho depth beneath the Chiapas coast of $\sim 35 \mathrm{~km}$ which is consistent with the results of Bravo et al. (2004) who give a Moho average depth beneath the Gulf of Tehuantepec of $28.5+/-3.5 \mathrm{~km}$. Also, the maximum extent of the rupture areas of past subduction earthquakes are in good agreement with the onset of the positive magnetic anomaly, and are therefore being controlled by the ductile serpentinized mantle wedge tip rather than by temperature (Figure 7). On the other hand, the updip seismogenic limit is controlled by temperature, the $100^{\circ} \mathrm{C}$ isotherm being in good agreement with the onset of rupture areas (Figure 9). 


\section{DISCUSSION AND CONCLUSIONS}

In this study we inferred the steady-state thermal structure beneath Chiapas using the numerical scheme proposed by Manea et al. (2005-C). The thermal models beneath the northernmost edge of CAVA successfully explain the calc-alkaline character of the magmatic products (Figure 3C,D). Also the thermal model for the flat slab just northwest of TR predicts the origin of the calc-alkaline and alkaline magmas of the TVF (Figure 3A). The only model which is not consistent with the position of the active volcanic arc is the model located just southeast of the TR beneath MCVA (Figure 3A). Also the position and the alkaline character of the El Chichón volcano cannot be explained by this model. To address these issues, we proposed an alternative model in which a mantle wedge flow perturbation is produced by a strong intake related with the space-time history of the subducting slab beneath Central Mexico (Ferrari et al., 1999). The flattening of the slab 17 Ma ago, would have produced a strong mantle wedge flow from NW to $\mathrm{SE}$, forming the MCVA. The migration of the intake further southeast can be seen in the age distribution of magmatic rocks through the MCVA (Damon and Montesinos, 1978) (Figure 6). The

cessation of the ancient Miocene Sierra Madre volcanic arc suggests that the mantle wedge beneath should be cold enough to prevent mantle wedge melting. We argue that the proximity of the flat slab is responsable for this cooling down. To constrain such model we use the availability of aeromagnetic data offshore Chiapas (Figure 9). A good correlation between the strong positive magnetic anomaly and the serpentinized mantle wedge suggests that the mantle wedge beneath the extinct Miocene Sierra Madre arc is sufficiently cold $\left(\mathrm{T}<600^{\circ} \mathrm{C}\right)$ to prevent melting (Figure 7).

Although these models offer a reasonable explanation for the origin of the MCVA, there is still an important unknown left: El Chichón volcano. De Ignacio et al. (2003) proposed an astenospheric intake through major faults in the subducting Cocos slab. This intake would have melted the oceanic slab and produced adakitic magmas. Unfortunately, this scenario is very difficult to prove, because we have to assume that the Cocos slab beneath Chiapas is segmented and decoupled in different blocks along slab dip faults. If this is the case, then the two parts of the subducting slab, northwest and southeast of TR, are completely decoupled. But an interesting thing can be readily observed in Figure 3: although in front of Chiapas the oceanic plate is older ( $29+/-$ 3 Ma from Manea et al., 2005-B), and therefore denser, just southeast TR, its dip is smaller than the slab dip further south where the slab is younger ( $23 \mathrm{Ma}$ ). This paradox can be easily explained by the existence of the flat subduction just northwest of TR, which actually does not allows the steeper slab to sink freely into the asthenosphere, therefore proving the nonexistence of such faults in the 
Cocos slab. Since the model of De Ignacio et al. (2003) looks quite unrealistic, we have to look for an alternative model in order to explain the singularity of El Chichón volcano within MCVA. There is a striking correlation between the TR and the position of El Chichón volcano, also pointed out by. It is known that the long-offset fracture zones are subject to a double serpentinization process due to bend-faulting at the outer rise (East pacific Rise for the TR) and at the trench axis. These faults might be conduits for seawater to react with the slab lithosphere and serpentinize it. If so, then such long fracture zones might produce tears beneath volcanic arc because they are water rich, therefore favoring more melting just above the slab surface. Indeed, a strong positive magnetic anomaly is observed along the TR (Figure 8), suggesting that the slab-lithosphere might be highly serpentinized. The slab geotherm through the slab-lithosphere (Figure 4B) for the cold thermal model (Figure $7 B$ ) shows that 10 \%wt might be released into the mantle at greater depths between 100 and $150 \mathrm{~km}$, close beneath the El Chichón volcano. Since El Chichón volcano is very young ( $0.2 \mathrm{Ma}$ ), we argue that this might reflect the arrival of the serpentinized TR beneath the MCVA at least 0.2 Ma ago, resulting from an instantaneous magma rise through the mantle. Assuming a constant convergence rate of $7 \mathrm{~cm} / \mathrm{yr}$, the TR would have commenced subduction at least $\sim 6 \mathrm{Ma}$ ago. 


\section{FIGURE CAPTIONS}

\section{Figure 1.}

Tectonic setting and position of the four modeled cross-sections (straight transparent lines). Transparent red zones show the location of active volcanic belts in Mexico and Guatemala: CMVB - Central Mexican Volcanic Belt, TVF - Los Tuxtlas Volcanic Front, MCVA - Modern Chiapanecan Volcanic Arc, CAVA - Central American Volcanic Arc. Transparent gray area: the extinct Sierra Madre Miocenic Arc. Orange stars are the main active volcanoes on each crosssection. Arrows show convergence velocities (above the arrows) between the Cocos and North American and Carribean plates (DeMets et al., 1994). The Cocos plate ages are shown beneath the arrows (Manea at al. 2005-C; Kanjorsky, 2003; Klitgord and Mammerickx, 1982).

\section{Figure 2.}

The left (seaward) boundary condition is a one-dimensional geotherm for the oceanic plate for ages of $16 \mathrm{Ma}, 23 \mathrm{Ma}$ and $26 \mathrm{Ma}$ respectively. Notice the lower thermal gradient for older incoming plate.

\section{Figure 3.}

Steady-state thermal models with strong temperature-dependent viscosity in the mantle wedge for the four cross-section shown in Figure 1. The rheological parameters used are: a reference viscosity of $10^{20} \mathrm{~Pa} \mathrm{~s}$ and activation energy for olivine of $250 \mathrm{~kJ} / \mathrm{mol}$ (Manea et al., 2004). Notice the high temperature beneath the active volcanic arcs (1200-1300 $\mathrm{C})$ except for profile B-B'. The earthquakes with magnitudes, $\mathrm{Mw}>5.5$, are represented by the black dots (compilation from: Rebollar et al., 1999; Engdahl and Villaseñor, 2002). Horizontal black dashed line shows the Moho. Topography is represented with 10x vertical exaggeration.

\section{Figure 4.}

A/ Phase diagrams for the MORB (Hacker et al., 2003). 1 - zeolite (4.6 wt.\% $\mathrm{H}_{2} \mathrm{O}$ ), 2 prehnite pumpellyite (4.5 wt.\% $\mathrm{H}_{2} \mathrm{O}$ ), 3 - pumpellyite actinolite (4.4 wt.\% $\left.\mathrm{H}_{2} \mathrm{O}\right), 4$ - greenschist (3.3 wt.\% $\mathrm{H}_{2} \mathrm{O}$ ), 5 - lawsonite blueschist (5.4 wt.\% $\mathrm{H}_{2} \mathrm{O}$ ), 6 - epidote blueschist (3.1 wt.\% $\mathrm{H}_{2} \mathrm{O}$ ), 7 epidote amphibolite (2.1 wt.\% $\mathrm{H}_{2} \mathrm{O}$ ), 8 - jadeite epidote blueschist (3.1 wt.\% $\mathrm{H}_{2} \mathrm{O}$ ), 9 - eclogite amphibole (2.4 wt.\% $\mathrm{H}_{2} \mathrm{O}$ ), 10 - amphibolite (1.3 wt.\% $\mathrm{H}_{2} \mathrm{O}$ ), 11 - garnet amphibolite (1.2 wt.\% $\left.\mathrm{H}_{2} \mathrm{O}\right), 12$ - granulite $\left(0.5\right.$ wt.\% $\left.\mathrm{H}_{2} \mathrm{O}\right), 13$ - garnet granulite $\left(0.0\right.$ wt. $\left.\% \mathrm{H}_{2} \mathrm{O}\right), 14$ - jadeite lawsonite 
blueschist (5.4 wt.\% $\mathrm{H}_{2} \mathrm{O}$ ), 15 - lawsonite amphibole eclogite (3.0 wt.\% $\left.\mathrm{H}_{2} \mathrm{O}\right), 16$ - jadeite lawsonite talc schist, 17 - zoisite amphibole eclogite $\left(0.7\right.$ wt.\% $\left.\mathrm{H}_{2} \mathrm{O}\right), 18$ - amphibole eclogite $\left(0.6\right.$ wt.\% $\left.\mathrm{H}_{2} \mathrm{O}\right)$, 19 - zoisite eclogite ( 0.3 wt.\% $\left.\mathrm{H}_{2} \mathrm{O}\right), 20$ - eclogite $\left(0.1\right.$ wt.\% $\left.\mathrm{H}_{2} \mathrm{O}\right), 21$ - coesite eclogite $(0.1$ wt.\% $\left.\mathrm{H}_{2} \mathrm{O}\right)$, 22 - diamond eclogite $\left(0.1\right.$ wt. $\left.\% \mathrm{H}_{2} \mathrm{O}\right)$.

B/ Phase diagram for harzburgite (Hacker et al., 2003). A - serpentine chlorite brucite (14.6 wt. $\% \mathrm{H}_{2} \mathrm{O}$ ), B - serpentine chlorite phase A (12 wt. $\% \mathrm{H}_{2} \mathrm{O}$ ), C - serpentine chlorite dunite (6.2 wt.\% $\mathrm{H}_{2} \mathrm{O}$ ), D - chlorite harzburgite $\left(1.4\right.$ wt.\% $\mathrm{H}_{2} \mathrm{O}$ ), E - talc chlorite dunite (1.7 wt.\% $\left.\mathrm{H}_{2} \mathrm{O}\right), \mathrm{F}$ anthigorite chlorite dunite (1.7 wt.\% $\mathrm{H} 2 \mathrm{O}), \mathrm{G}$ - spinel harzburgite $\left(0.0\right.$ wt.\% $\left.\mathrm{H}_{2} \mathrm{O}\right), \mathrm{H}$ - garnet harzburgite $\left(0.0 \mathrm{wt} . \% \mathrm{H}_{2} \mathrm{O}\right)$.

The slab geotherms intersect the dehydration melting solidus for basalt only for profile A-A'. For profiles C-C' and D-D' strong dehydration ( $\sim 5$ wt.\%) occurs just beneath the active volcanic arc. The geotherm B-B' cold top is for the model with a cold mantle wedge beneath the extinct Sierra Madre Miocene volcanic arc. (Figure 7B). The geotherm B-B' cold btm. represents the geotherm at the base of the oceanic crust. Note the strong dehydration ( $10 \mathrm{wt} . \%)$ released into the mantle at greater depths between 100 and 150 km, close beneath the El Chichón volcano.

\section{Figure 5.}

Space-time distribution of the volcanic arcs in Central and South Mexico (data from Ferrari et al., 1999; Damon and Montesinos, 1978).

A/ 25 - 17 Ma: the volcanic arc formed an approximatively continuous belt.

B/ 17 - 12 Ma: the CMVB moved inland, suggesting that the subducting slab become subhorizontal.

C/ 12 - 7 Ma: the flattening process of the Cocos slab continued further SE. The proximity of the new cold flat subducting lithosphere with the hot mantle wedge beneath Chiapas, would eventually lead to a progressively CAVA extinction in southern Mexico.

D/ 7 - 3 Ma: the CAVA continued to retreat SE and the volcanic activity close to the Chiapas coast ceased completely. Also, the TVF is born during this period.

E/ 3 - 0 Ma: The up bending of the subducting slab for the last 14 Ma created an asthenospheric inflow from NW to SW, which finally lead to the onset of the MCVA. 


\section{Figure 6.}

The isotopic ages along the MCVA decrease from NW to SE (data from: Damon and Montesinos, 1978), suggesting that the arc was propagating through time from NW to SE. Note the anomalous position of the El Chichón volcano.

\section{Figure 7.}

A/ Red line: Low pass filtered aeromagnetic anomaly along profile B-B'. Blue line is the same aeromagnetic anomaly but migrated to the pole, so the source is just beneath the peak. Dashed lines represent our extrapolation where real data is missing.

B/ Steady-state thermal model with a cold mantle wedge tip and a hot asthenospheric region beneath MCVA. The foggy triangle represents the serpentinized mantle wedge. Note the good corelation with the position of the pole migrated aeromagnetic anomaly.

\section{Figure 8.}

3D conceptual model where can be seen that the mantle wedge beneath Chiapas lies just in front of a cold area which corresponds to the incoming flat slab. Also the hot asthenospheric inflow is shown.

\section{Figure 9.}

Aeromagnetic map for Central and South Mexico. The white areas represent no data. Note the prominent high-amplitude magnetic anomalies offshore Chiapas (white dotted line). The reduced to pole anomaly is shifted inland (black dotted line). This anomaly is used to project onto the surface the serpentized mantle wedge (transparent white area). Note the good agreement between the rupture areas and the $100^{\circ} \mathrm{C}$ isotherm and the onset of the serpentinized mantle wedge. Also note the high-amplitude magnetic anomalies along TR, which might be an indicator of a highly serpentinized region. 


\section{REFERENCES}

Bevis, M. and Isacks, B.L., 1984. Hypocentral trend surface analysis: probing the geometry of Benioff Zones. J. Geophys. Res., vol. 89, 6153-6170.

Blakely, R.J., Brocher, T.M., Wells, R.E., 2005. Subduction-zone magnetic anomalies and implications for hydrated forearc mantle. Geology, G21447.

Bostock, M.G., Hyndman, R.D., Rondenay, S., and Peacock, S.M., 2002. An inverted continental Moho and serpentinization of the forearc mantle. Nature, vol. 417, pp. 536-538.

Bravo, H, Rebollar, C.J., Uribe, A., and Jimenez, O., 2004. Geometry and state of stress of the Wadati-Benioff zone in the Gulf of Tehuantepec, Mexico. J. Geophys. Res., vol. 109, B04307, doi:10.1029/2003JB002854.

Christensen, N.I., 1966. Elasticity of ultrabasic rocks. J. Geophys. Res., vol. 71, pp. 5921-5931.

Damon, P.E., and Montesinos, E., 1978. Late Cenozoic volcanism and metallogenesis over an active Benioff zone in Chiapas, Mexico. Arizona Geological Soc. Digest, X1, pp. 155-168.

De Ignacio, C., Castineiras, P., Marquez, A., Oyarzun, R., Lillo, J., Lopez, I., 2003. El Chichón volcano (Chiapas volcanic belt, Mexico) transitional calc-alkaline to adakitic-like magmatism: Petrologic and tectonic implications. Int. Geol. Rev., 45, pp. 1020-1028.

DeMets, C., Gordon, R., Argus, D., and Stein, S., 1994. Effect of recent revisions to the geomagnetic reversal time scale on estimates of current plate motions, Geophys. Res. Lett, vol. 21, pp. 2191-2194.

Engdahl, E. R. and Villaseñor, A., 2002. Global seismicity: 1900-1999, in Lee, W. H. K. et al. (editors), International handbook of earthquake engineering and seismology, International Geophysics series, vol. 81A, 665- 690.

Ferrari, L., López-Martinez, M., Aquirre-Díaz, G., and Carrasco-Núñez, G., 1999. Space-time patterns of Cenozoic arc volcanism in central Mexico: from the Sierra Madre Occidental to the Mexican Volcanic Belt. Geology, vol. 27, no. 4, pp. 303-306.

Fischer, K. M., Parmentier, E. M., Stine, A. R., and Wolf, E. R., 2000. Modeling anisotropy and plate-driven flow in the Tonga subduction zone back-arc, J. Geophys. Res., vol. 105, pp. 16,181$16,191$.

García-Palomo, A., Macías, J.L., Espíndola, J.M., 2004. Strike-slip faults and K-alkaline volcanism at El Chichón volcano southeastern Mexico. J. Volcanol. Geotherm. Res.,136, pp. 247268.

Guzmán-Speziale, M., and Meneses-Rocha, J.J., 2000. The North America-Caribbean plate 
boundary west of the Motagua-Polochic fault system: a fault jog in Southeastern Mexico. J. South Amer. Earth Sci., 13, pp. 459-468.

Hacker, B.R., Abers, G.A., Peacock, S.M., 2003. Subduction factory 1. Theoretical mineralogy, densities, seismic wave speeds, and $\mathrm{H}_{2} \mathrm{O}$ contents. J. Geophys. Res., vol. 108, doi: 10.1029/2001JB001127.

Kanjorski, M.N., 2003. Cocos Plate structure along the Middle America subduction zone off Oaxaca and Guerrero, Mexico: influence of subducting plate morphology on tectonics and seismicity. PhD thesis, University of California, San Diego.

Klitgord, K.D., and Mammerickx, J., 1982. Northern east Pacific Rise; magnetic anomaly and bathymetric framework. J. Geophys. Res., vol. 87, 138, pp. 6725-6750.

Luhr, J.F., Carmichael, I.S.E., Varekamp, J.C., 1984. The 1982 eruptions of El Chichón Volcano, Chiapas, Mexico: mineralogy and petrology of the anhydrite-bearing pumices. J. Volcanol. Geotherm. Res., 23, pp. 69-108.

Macías, J.L., Arce, J.L., Mora, J.C., Espíndola, J.M., Saucedo, R., Manetti, P., 2003. The 550 bp Plinian eruption of el Chichón volcano, Chiapas, Mexico: explosive volcanism linked to reheating of a magma chamber. J. Geophys. Res., 108, 1-18. ECV3.

Manea, V.C., Manea, M., Kostoglodov, V., Currie, C.A., and Sewell, G., 2004. Thermal Structure, Coupling and Metamorphism in the Mexican Subduction Zone beneath Guerrero. Geophysical Journal International, 158, 775-784.

Manea, M., Manea, V.C., Kostoglodov, V., and Guzman-Speziale, M., 2005-A. Elastic Thickness of the Lithosphere below the Tehuantepec Ridge. Geofisica International, vol.44, no. 2.

Manea, M., Manea, V.C., Ferrari, L., and Kostoglodov, V., 2005-B. Structure and origin of the Tehuantepec Ridge. under revision, Earth Planet. Sci. Lett.

Manea, V.C., Manea, M., Kostoglodov, V., and Sewell, G., 2005-C. Thermo-mechanical model of the mantle wedge in Central Mexican subduction zone and a blob tracing approach for the magma transport. Phys. Earth Planet. Int., vol. 149, pp. 165-186. doi:10.1016/JPEPI2004.08.024 Nelson, S.A., Gonzalez-Caver, E., and Kyser, T.K., 1995. Constraints on the origin of alkaline and calc-alkaline magmas from the Tuxtla Volcanic Field, Veracruz, Mexico. Contrib. Mineral. Petrol., 122, pp. 191-211.

Nixon, G.T., 1982. The relationship between Quaternary volcanism in central Mexico and the seismicity and structure of the subducted ocean lithosphere. Geol. Soc. Am. Bull., 93, pp. 514-523. North American Magnetic Anomaly Group (NAMAG), 2002. Magnetic Anomaly Map of North America. Processing, Compilcation, and Geologic Mapping Applications of the new digital 
magnetic anomaly database and map of North America. Printed by U.S. Department of the Interior and U.S. Geological Survey.

Rebollar, C.J., Espindola, V.H., Uribe, A., Mendoza, A., and Vertti, A.P., 1999. Distributions of stresses and geometry of the Wadati-Benioff zone under Chiapas, Mexico. Geofisica Int., vol. 38, no. 2, pp. 95-106.

Saad, A.F., 1969. Magnetic properties of ultramafic rocks from Red Mountain, California. Geophysics, vol. 34, pp. 974-987.

Wyllie, P.J., 1979. Magmas and volatile components. American Mineralogy, v. 654, pp. 469-500. 


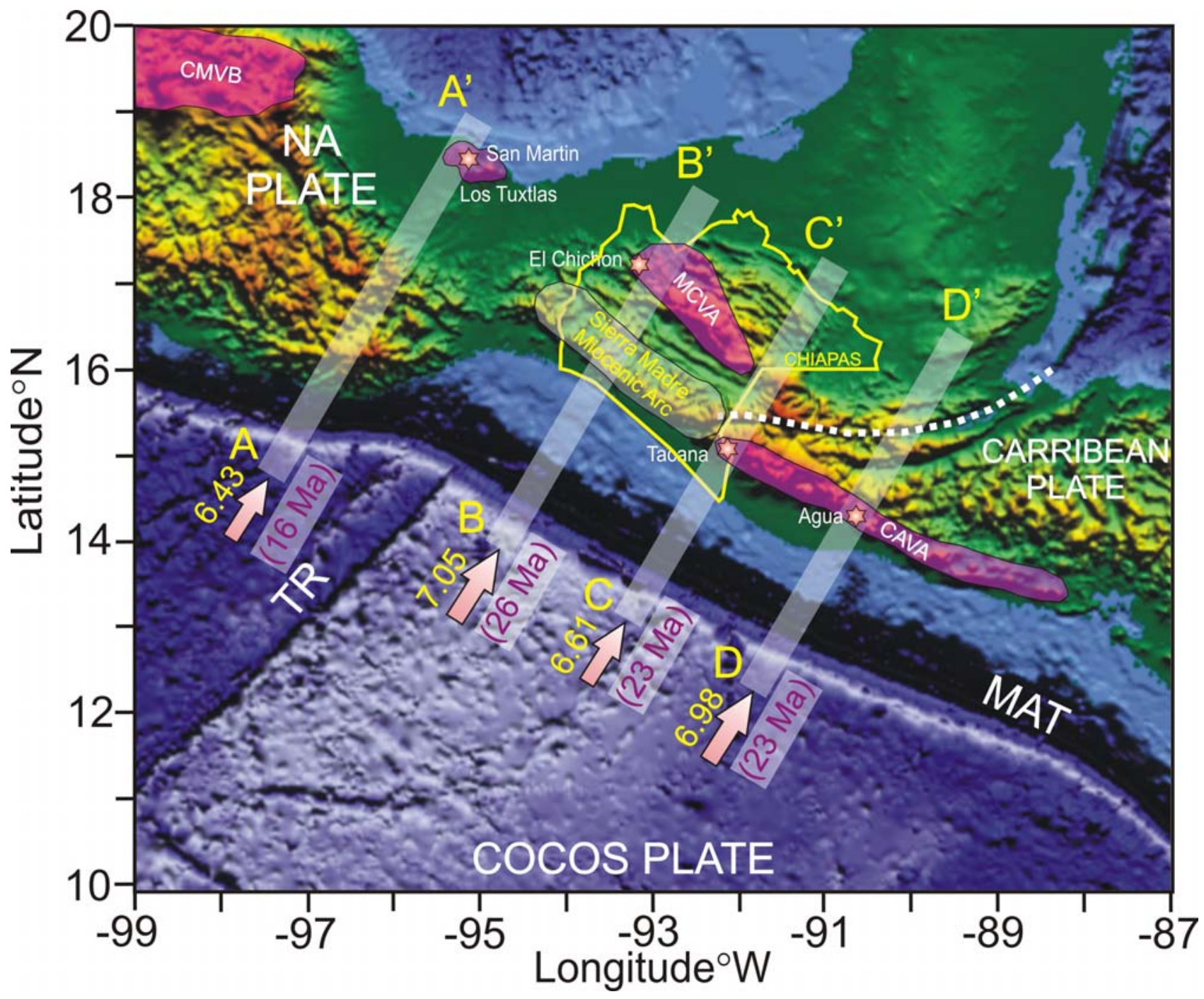

Figure 1 


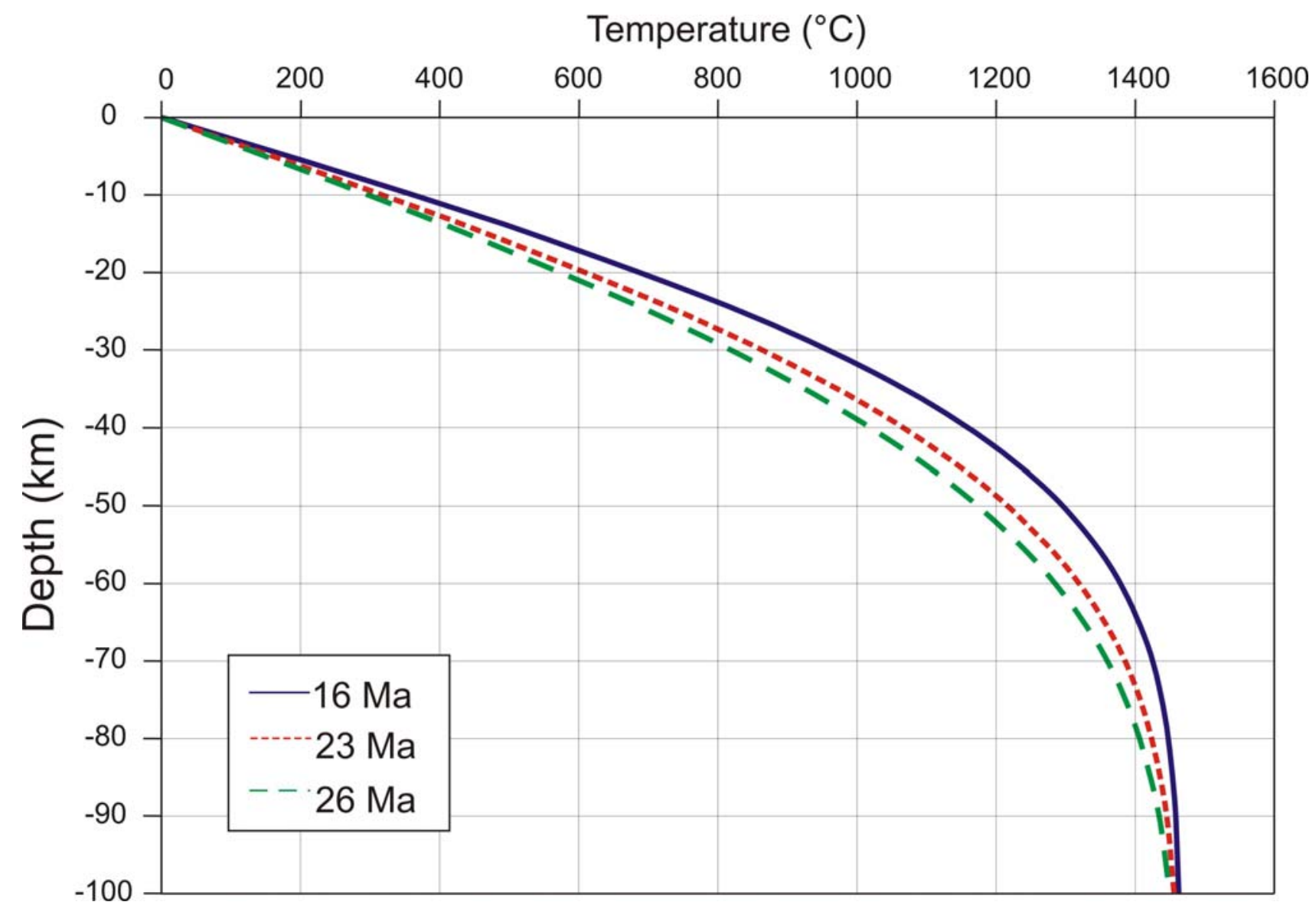

Figure 2 

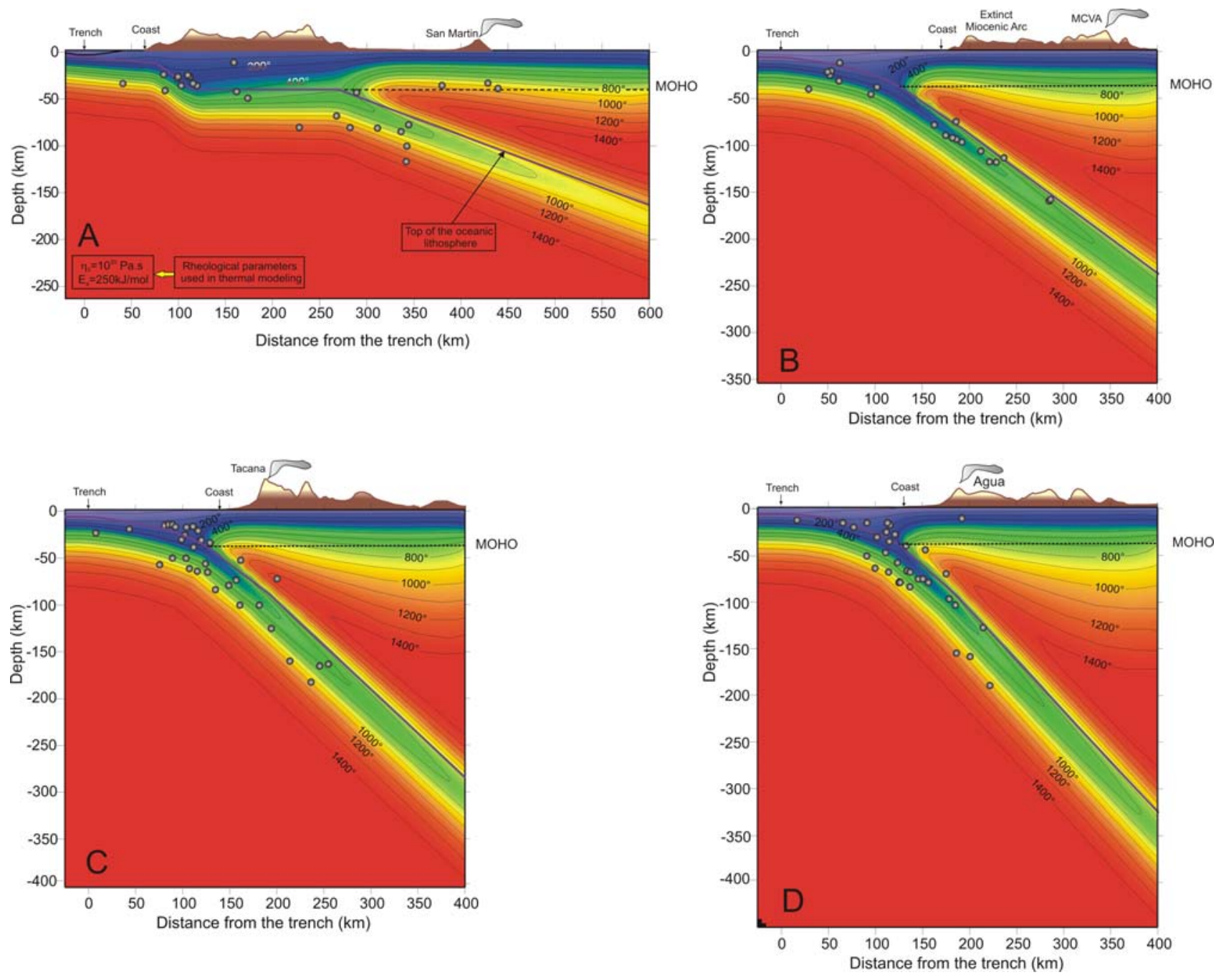

Figure 3 

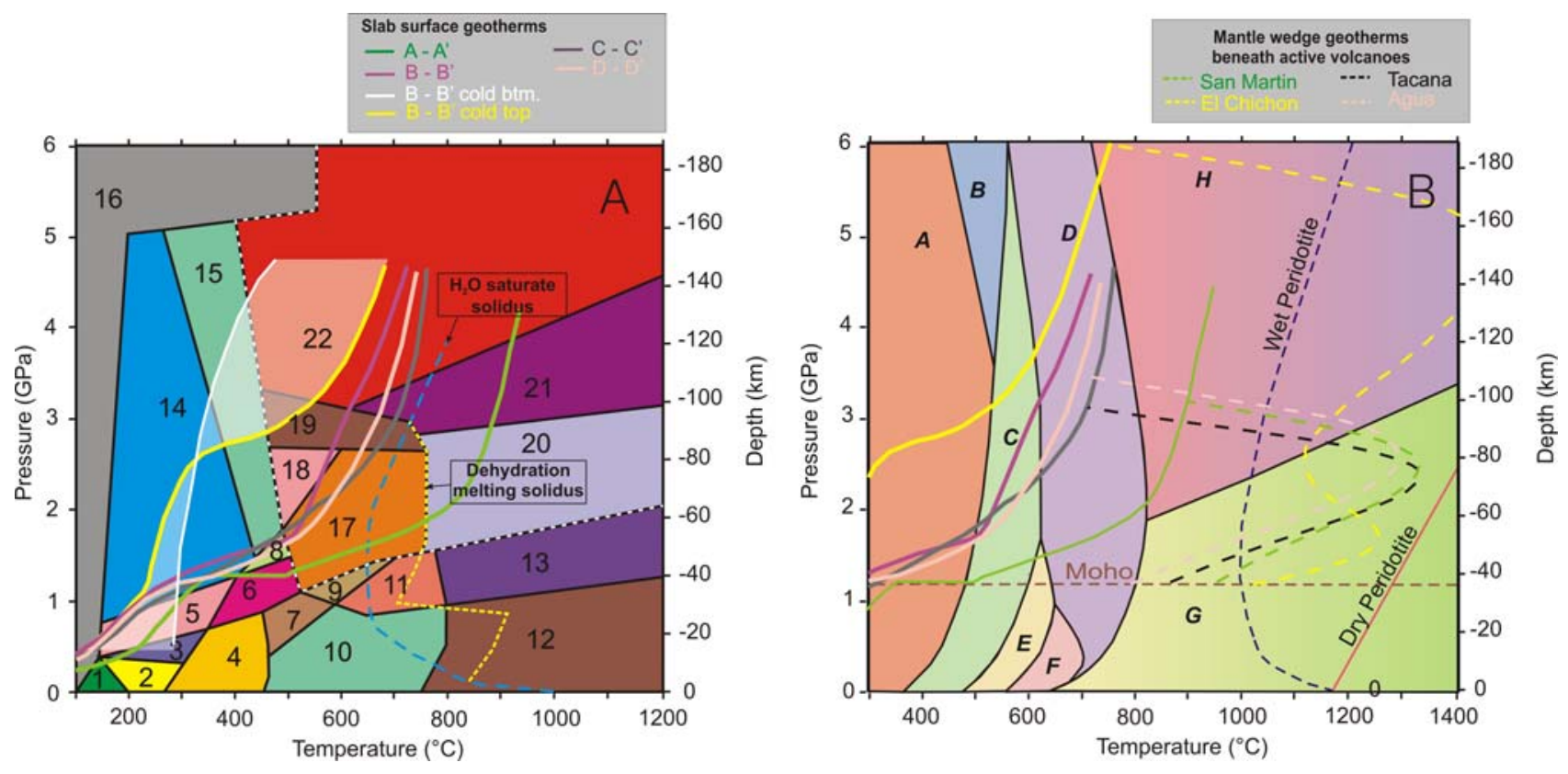

Figure 4 

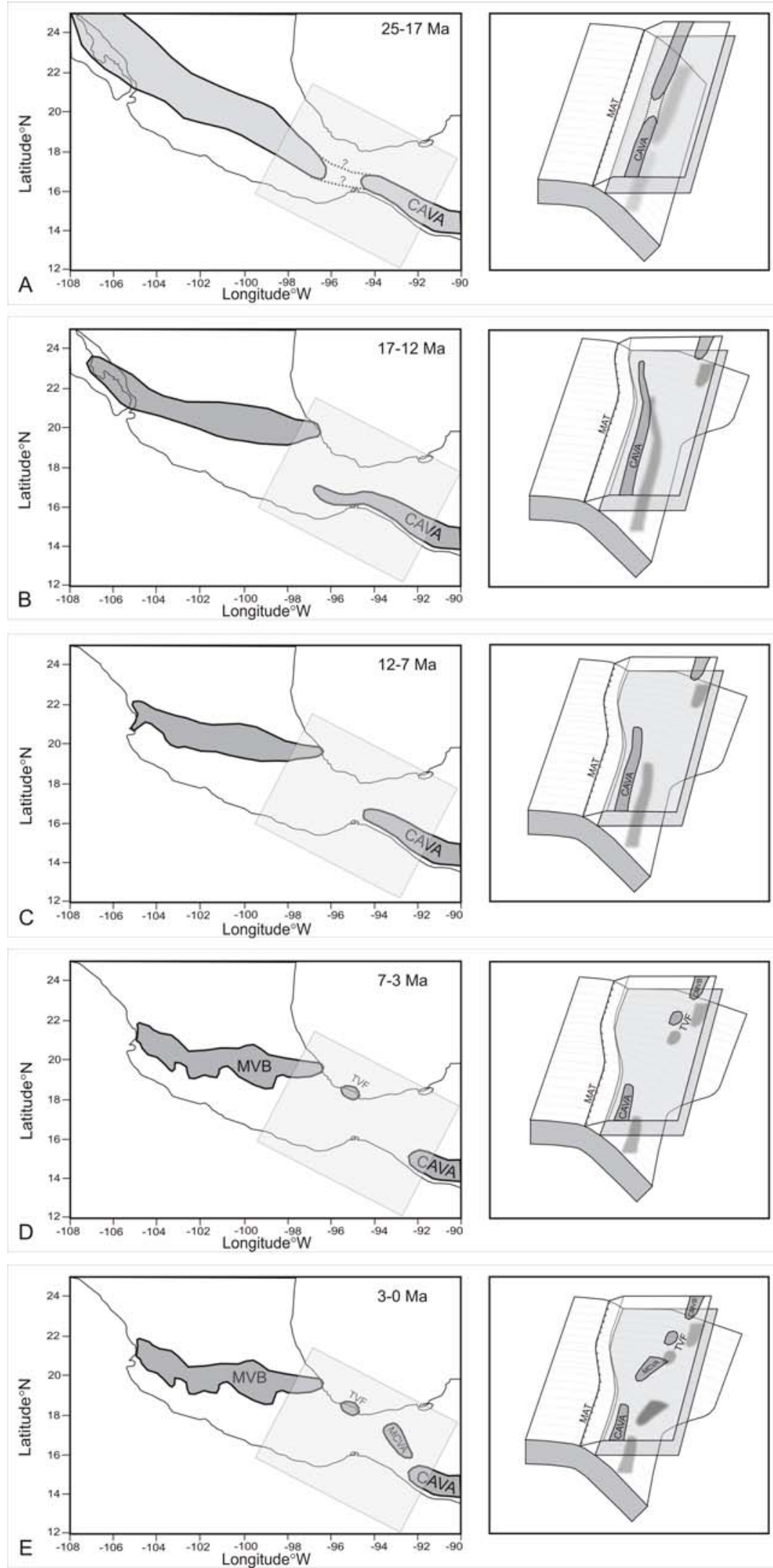

Figure 5 


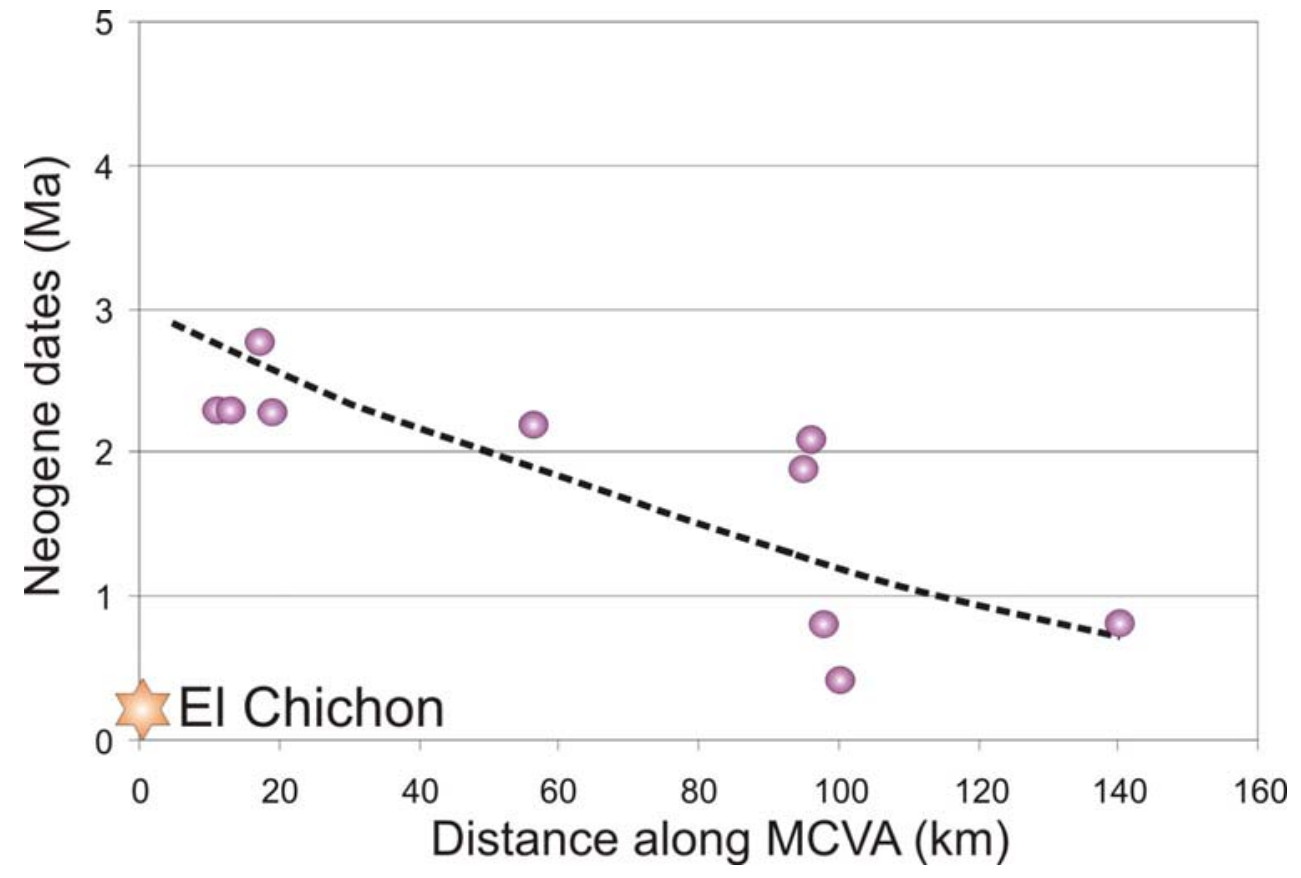

Figure 6 


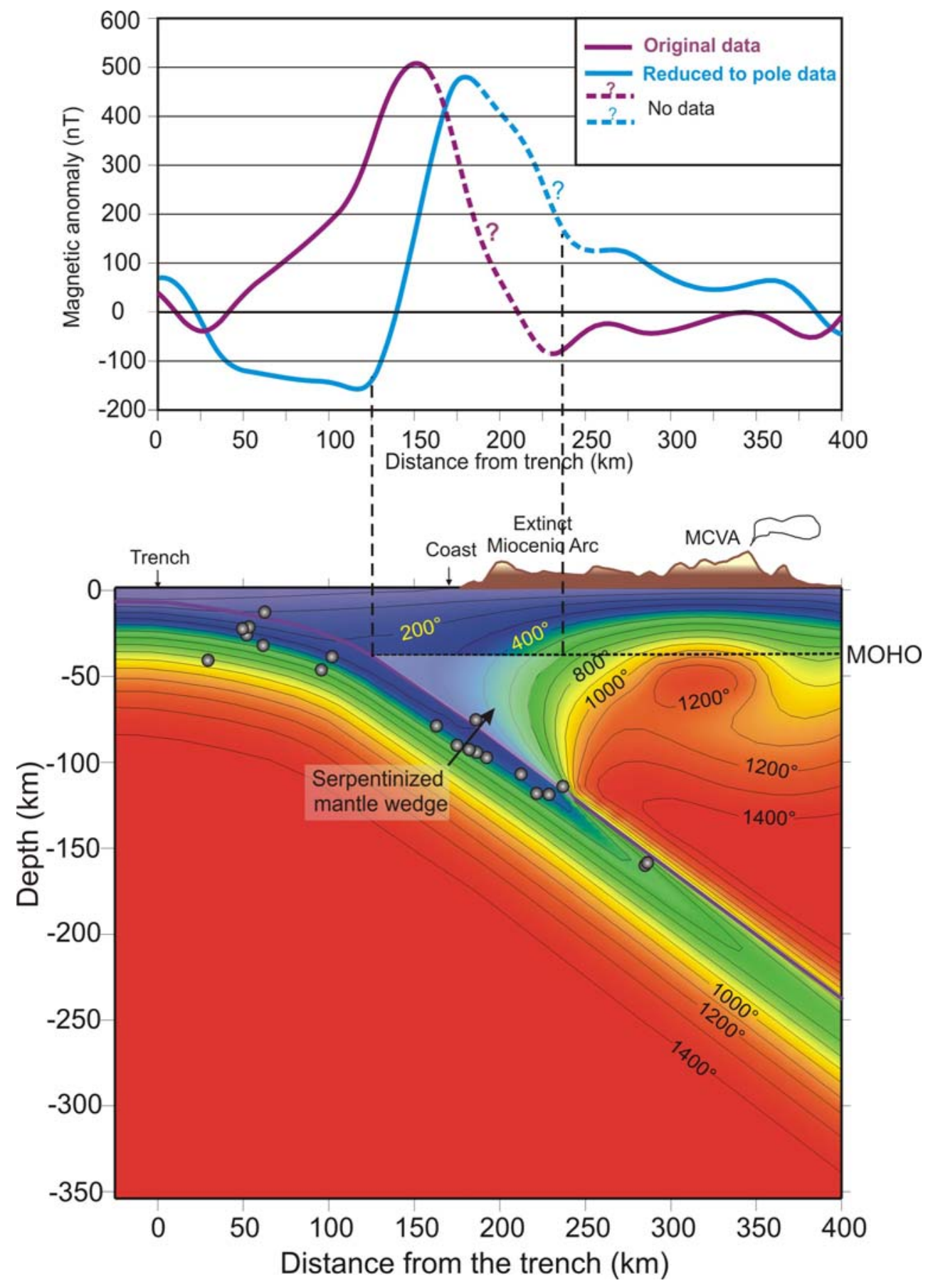

Figure 7 


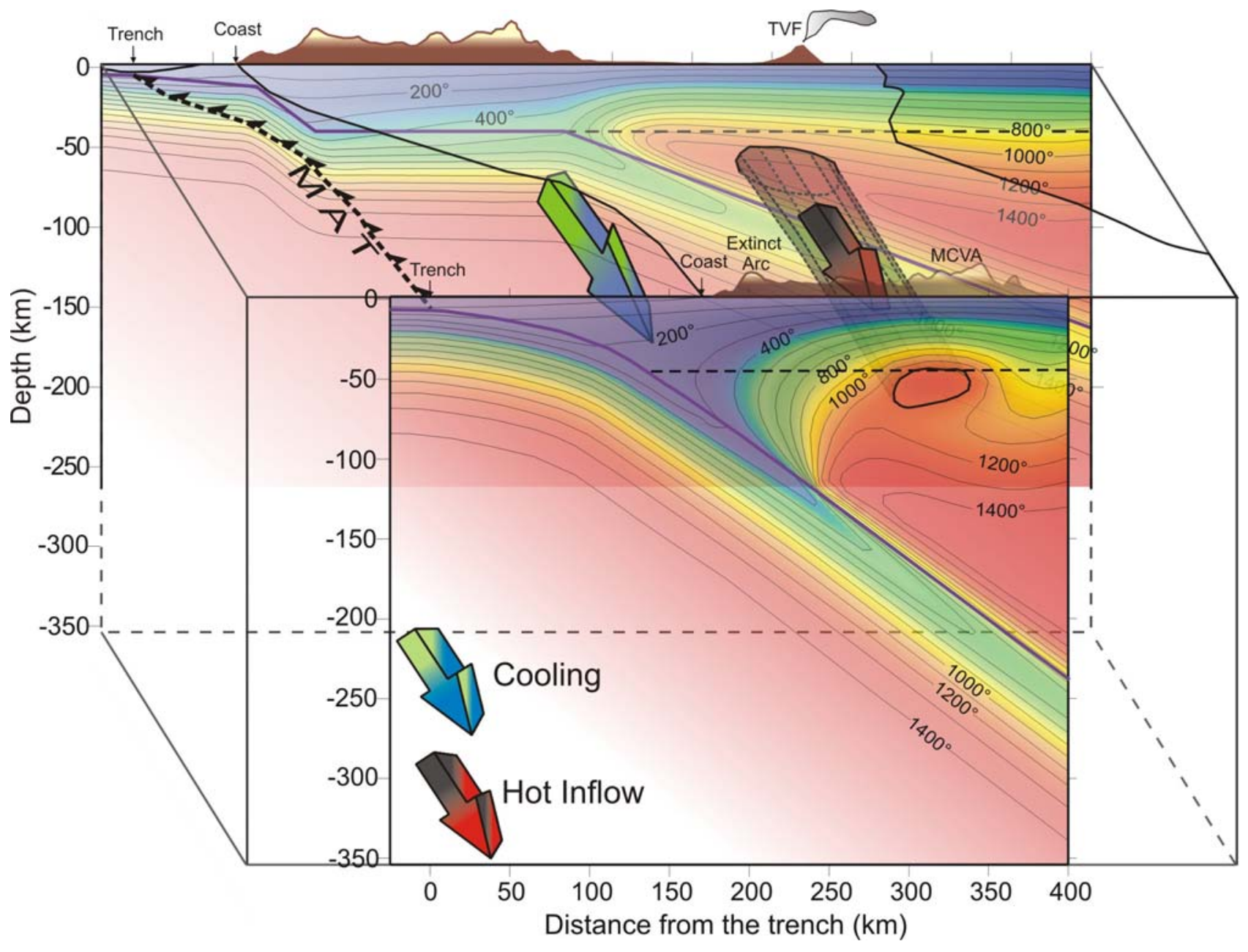

Figure 8 


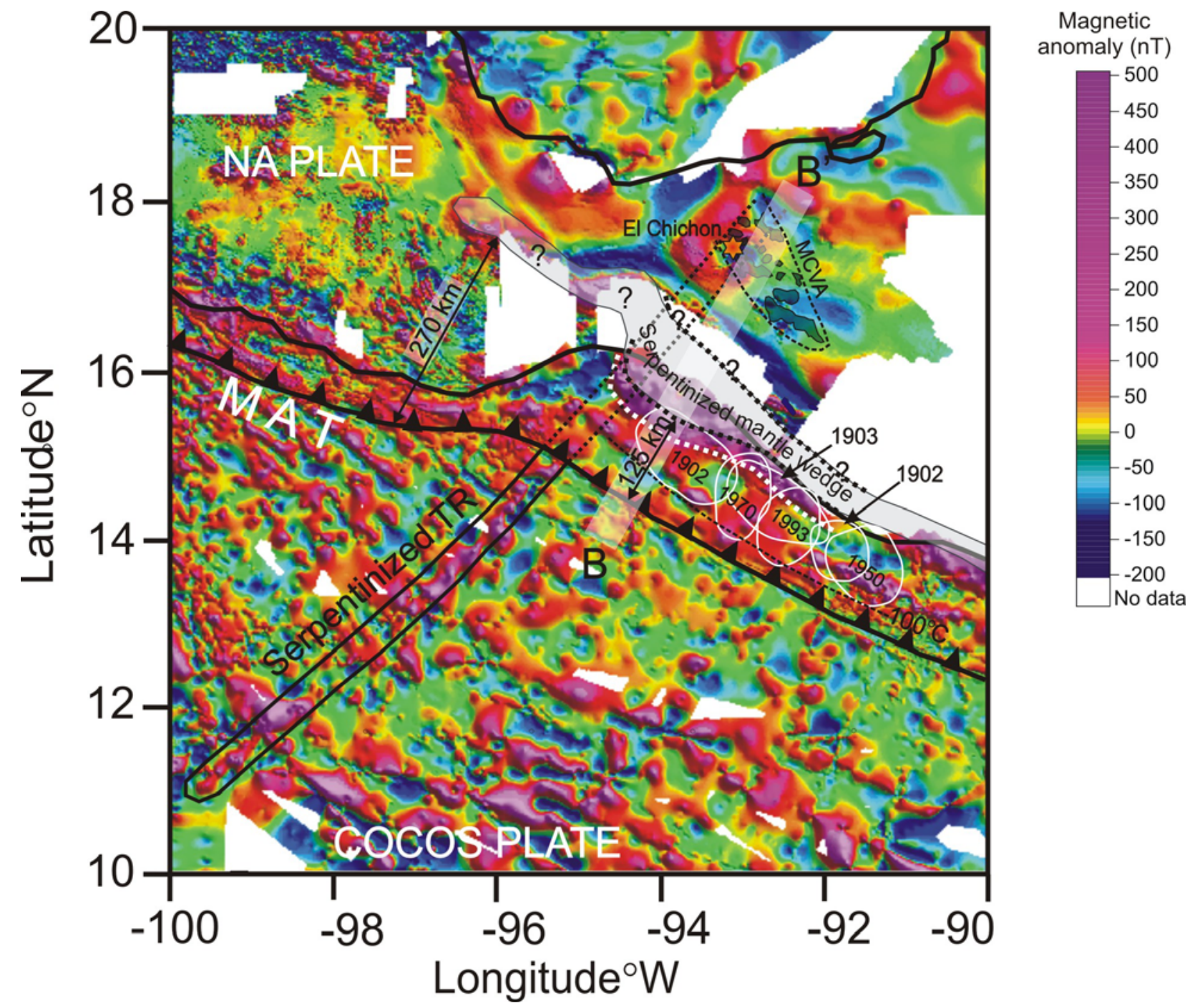

Figure 9 